\title{
FURTHER EVIDENCE FROM CENSUS 2000 ABOUT EARNINGS BY DETAILED OCCUPATION FOR MEN AND WOMEN: THE ROLE OF RACE AND HISPANIC ORIGIN
}

by

\author{
Daniel H. Weinberg* \\ U.S. Bureau of the Census
}

CES 11-37

November, 2011

The research program of the Center for Economic Studies (CES) produces a wide range of economic analyses to improve the statistical programs of the U.S. Census Bureau. Many of these analyses take the form of CES research papers. The papers have not undergone the review accorded Census Bureau publications and no endorsement should be inferred. Any opinions and conclusions expressed herein are those of the author(s) and do not necessarily represent the views of the U.S. Census Bureau. All results have been reviewed to ensure that no confidential information is disclosed. Republication in whole or part must be cleared with the authors.

To obtain information about the series, see www.census.gov/ces or contact Cheryl Grim, Editor, Discussion Papers, U.S. Census Bureau, Center for Economic Studies 2K130B, 4600 Silver Hill Road, Washington, DC 20233, CES.Papers.List@census.gov. 


\begin{abstract}
A 2004 report by the author reviewed data from Census 2000 and concluded "There is a substantial gap in median earnings between men and women that is unexplained, even after controlling for work experience (to the extent it can be represented by age and presence of children), education, and occupation.” This paper extends the analysis and concludes that once those characteristics are controlled for, no further explanatory power is attributable to race or Hispanic origin.
\end{abstract}

*Daniel Weinberg is Senior Research Scientist, U.S. Census Bureau. This paper is released to inform interested parties of research and to encourage discussion. Any opinions and conclusions expressed herein are those of the author and do not necessarily represent the views of the U.S. Census Bureau. All results have been reviewed to ensure that no confidential information is disclosed. The author wishes to thank Kirk Davis for his stellar programming support, Philip Gbur for his statistical assistance, and B.K. Atrostic and Barbara Downs for their comments and suggestions. 


\section{INTRODUCTION}

People are curious as to what others earn in their jobs. Career counselors need to tell their clients what wage or salary to expect from a particular occupation; those concerned about gender discrimination in hiring and promotions need to know what others earn so they can investigate claims; and workers claiming loss of wages due to injuries need to know the profile of earnings by age and occupation. The list of those wanting to know more about wages and earnings seems endless.

Of particular interest is the ratio of women's earnings to men’s earnings. The U.S. Census Bureau recently reported that, "In 2010, the female-to-male earnings ratio of full-time, year-round workers was 0.77.” While unchanged from 2009, this ratio was well above the ratio of 0.64 recorded for 1955, the first year for which the Census Bureau calculated the ratio. ${ }^{1}$

This paper extends an earlier analysis of the ratio of female-to-male median earnings, as reported on the Census 2000 long form. It uses the same methodology as Census 2000 Special Report CENSR-15, Evidence from Census 2000 about Earnings by Detailed Occupation for Men and Women. ${ }^{2}$ This paper examines occupational differences in median earnings for men and women by race and Hispanic Origin as reported in Census 2000. ${ }^{3}$ Earnings include wages,

1. Carmen DeNavas-Walt, Bernadette D. Proctor, and Jessica C. Smith. Income, Poverty, and Health Insurance Coverage in the United States: 2010. (U.S. Census Bureau Current Population Reports P60239, September 2011), at < http://www.census.gov/prod/2011pubs/p60-239.pdf >.

2. Daniel H. Weinberg, Evidence from Census 2000 about Earnings by Detailed Occupation for Men and Women. U.S. Census Bureau Census 2000 Special Report CENSR-15, May 2004, at $<$ http://www.census.gov/prod/2004pubs/censr-15.pdf>.

3. Questions about earnings and occupation are no longer asked on the decennial census. Instead, starting in 2005, they are asked monthly on the American Community Survey, and aggregated into 1-, 3-, and 5year period estimates depending on the level of detail and geographic level needed. 
salaries, and self-employment income. ${ }^{4}$ Census 2000 classified occupations into 509 categories

based on the 2000 Standard Occupational Classification (which contains 821 detailed

occupations)..$^{5}$

Race is a complex social construct about which much has been written. In 1977, the

Office of Management and Budget (OMB) issued its Statistical Policy Directive 15, which

provided the framework for federal data collection on race and ethnicity to federal agencies, including the Census Bureau for the 1980 and 1990 decennial censuses. The OMB directed agencies to focus on data collection for four racial groups in that year- White; Negro or Black; American Indian, Eskimo, or Aleut; and Asian or Pacific Islander - and one ethnicity - Hispanic, Latino, or Spanish origin. The questions on the 1980 and 1990 censuses asked individuals to self-identify with one of these four racial groups and whether they were Hispanic or not. ${ }^{6}$

4. Wages are sometimes distinguished from salaries by the time period that is the basis for payment. Wage earners are often hourly employees while salaried individuals are usually paid an annual salary. This distinction between wage and salary income is not universally applied, so the Census Bureau treats them the same. Earnings is but one component of income, which includes other sources such as interest, dividends, transfer program benefits, and so forth.

5. The Standard Occupational Classification (SOC) is a system for classifying all occupations in the economy in which work is performed for pay or profit. The occupations in the 2000 SOC were classified at four levels of aggregation. Each occupation is classified in exactly one of 23 major groups, 96 minor groups, 449 broad occupations, and 821 detailed occupations. A detailed description of each occupation and the SOC principles can be found in Executive Office of the President, Office of Management and Budget, Standard Occupational Classification Manual: 2000, Washington DC: Bernan Associates/National Technical Information Service, October 2000. The 2010 SOC system contains 840 detailed occupations, aggregated into 23 major groups, 97 minor groups, and 461 broad occupations (see 2010 SOC User Guide, U.S. Bureau of Labor Statistics, February 2010 at $<$ http://www.bls.gov/soc/soc_2010_user_guide.pdf $>$.) This analysis excludes four Census occupations that are uniquely military occupations.

6. The Population Censuses have a special dispensation from OMB to allow individuals to designate "Some Other Race" rather than one of those specifically listed. The vast majority of individuals choosing that option are Hispanic (Grieco and Cassidy 2001). Because of Congressional directives, the decennial census questions also ask about specific Asian and Pacific Islander races (e.g., Chinese). 
OMB undertook a major effort in the 1990s to reexamine America's concept of race. After much research and public comment; it revised the Nation's racial classification to include five categories - White, Black or African American, American Indian or Alaska Native, Asian, and Native Hawaiian or other Pacific Islander. An additional major change was to permit the selfidentification of individuals as "one or more races." While a small fraction of the population had already been doing so on previous census forms, this new directive made this practice permissible in data collection activities. Census 2000 figures indicated that 6.8 million, or 2.4 percent of the population, designated themselves as multiracial. ${ }^{7}$

With the exception of Whites, all the race groups discussed in this report refer to people who chose a particular single racial identity or that race in combination with one or more other races; thus, some individuals can be in multiple groups. Statistics for comparison purposes are computed for non-Hispanic Whites - people who did not indicate a Hispanic or Latino ethnicity and chose only one race, White. ${ }^{8}$

OMB did not change the question or the basic self-identification approach to identifying individuals of Hispanic origin, though it did direct that such a question be placed before the question on race because scientific testing showed that such a placement reduced non-response. Individuals of Hispanic origin may be of any race. In Census 2000, 8.0 percent of single-race

7. Census 2000 Summary File 1, Table P3. In 2010, 9.0 million (2.9 percent) designated themselves as multiracial (Table DP-1, Profile of General Population and Housing Characteristics: 2010).

8. The use of this categorization does not imply that it is the preferred method of presenting or analyzing race-based data. The Census Bureau uses a variety of approaches. This paper does not investigate alternate classifications. 
Whites, 2.8 percent of Blacks, 16.4 percent of American Indians and Alaska Natives, 2.7 percent of Asians, and 14.4 percent of Native Hawaiians or other Pacific Islanders self-identified as Hispanic. $^{9}$

Figure 1 presents a comparison of minority group earnings to the earnings of nonHispanic Whites at each percentile of the earnings distribution in 1999. Asians had an earnings level at or above that for non-Hispanic Whites for most of the earnings distribution. In contrast, the other four groups - Blacks or African-Americans, Native Hawaiians and other Pacific Islanders, American Indians and Alaska Natives, and Hispanics - had earnings levels substantially below that for non-Hispanic Whites, with Hispanics having noticeably the lowest ratio over most of the distribution (between roughly the $5^{\text {th }}$ and $95^{\text {th }}$ percentiles). The remainder of the paper will focus on median earnings.

9. Census 2000 Summary File 1, Tables P8 and P10. In 2010, the figures were 12.0, 3.2, 12.4, 1.4, and 10.8 percent, respectively (Table DP-1, Profile of General Population and Housing Characteristics: 2010). 


\section{THE RATIO OF FEMALE-TO-MALE MEDIAN EARNINGS FOR YEAR-ROUND FULL-}

\section{$\underline{\text { TIME CIVILIAN WORKERS }}^{10}$}

Table 1 presents the percent female and the median earnings for year-round full-time civilian workers 16 years old or older (hereinafter termed YRFT workers or just workers). Yearround means an individual worked 50 or more weeks in 1999 (or is an elementary or secondary school teacher who worked 37 or more weeks). ${ }^{11}$ Full-time means the individual worked 35 or more hours a week. If these limitations had not been imposed, occupations where part-time or part-year work is prevalent would have lower earnings simply because of the fewer hours worked by some each year, not because of variation within the occupation for comparably employed individuals. Workers in the armed forces are excluded.

The median earnings of the 83.0 million YRFT workers in 1999 was $\$ 33,000$. Of all YRFT workers in 1999, 41.2 percent were women. The median woman earned \$28,000, 73.7 percent of the median man (\$38,000). Of YRFT workers in their prime earnings years (35 to 54), the median woman earned $\$ 30,000,71.4$ percent of the median man $(\$ 42,000)$.

The racial or ethnic group with the highest proportion of female YRFT workers was

10. The estimates in this report are based on responses from a sample of the population. As with all surveys, estimates may vary from the actual values because of sampling variation or other factors (see Accuracy of the Estimates). All statements made in this report have undergone statistical testing including adjustments for multiple comparisons and are significant at the 90-percent confidence level, unless otherwise noted. Differences that are not statistically different may still reflect "real" differences, especially as the width of confidence intervals depends on the size of the sample and the size of the occupation considered; uncertainty remains in the magnitude and direction of the difference. To protect confidentiality, all earnings figures are reported to two significant digits only and the number of workers is rounded to the nearest 10 . All calculations of derived ratios and percentages are done using unrounded estimates. Standard errors and confidence intervals are not presented because they are often smaller than rounding error.

11. Paid vacations count as weeks worked. 
Blacks, at 51.6 percent (the only group with a majority of workers as female); the lowest was Hispanics, at 37.3 percent. These estimates are quite similar for prime-age workers (ages 35 to $54)$.

The only racial or ethnic group to have a female-to-male median earnings ratio below the ratio for all workers was non-Hispanic Whites, at 72.3 percent overall and 67.8 percent for those aged 35-54. In contrast, all the other groups, with the exception of Asians (at 75.0 percent), had an earnings ratio at or above 80 percent for all workers. Hispanics had the highest ratio, at 88.0 percent. In contrast, for workers aged 35-54, Blacks had the highest ratio, at 84.1 percent.

\section{$\underline{\text { EARNINGS BY OCCUPATION }}^{12}$}

The most highly paid occupation overall, for men and women, and for men and women in each race (except American Indians and Alaska Natives) and for Hispanics is Physicians and surgeons (see Table 2). ${ }^{13}$ Median earnings appear to differ markedly between men and women more so than among the race-ethnicity groups. The other occupations to appear frequently on the “top five” lists for non-Hispanic Whites, Blacks, Asians, and Hispanics for men and women are Chief executives; Lawyers; and Dentists.

In contrast, there is much more comparability in the levels of median earnings of the

12. To make distinctions among occupations clearer for the reader, especially given the embedded commas in some titles, only the first letter of each occupation is capitalized, the title is shown in italics, and a series of titles is separated by semicolons. Only occupations with 10,000 or more year-round fulltime workers and at least 1,000 male and 1,000 female workers appear in the tables. There were no occupations for Native Hawaiians and other Pacific Islanders that met this criterion, and only three for American Indians and Alaska Natives (Elementary and middle school teachers, First-line supervisors/managers of retail sales workers, and Driver/sales workers and truck drivers).

13. There were fewer than 10,000 American Indian and Alaska Native Physicians and surgeons so it was not possible to determine if indeed this statement is also true for that racial group. 
lowest-paid occupations across the sexes and among the race-ethnicity groups (see Table 3).

Cooks is the most common occupation to appear on the "bottom five" lists for non-Hispanic Whites, Blacks, Asians, American Indians and Alaska Natives, and Hispanics, for both men and women (appearing for eight of ten lists).

\section{THE EFFECT OF DEMOGRAPHIC CHARACTERISTICS}

As noted in the earlier Census 2000 special report, education and occupation are likely to have a significant impact on earnings and consequently on the earnings ratio. Table 4 presents one perspective on the contributions of demographic characteristics to differences in median earnings between men and women. As noted earlier, the ratio of median earnings for women to median earnings for men, the female-to-male earnings ratio (FMER), is 0.737 for all year-round full-time workers. This ratio reflects differences in the characteristics of these men and women differences in age, education, occupation, and race and Hispanic origin.

To take account of the different distributions by age, education, race, ethnicity, and occupation, the FMER is calculated at the most disaggregated level appropriate for the analysis, and then aggregated to a total using the share of the total number of workers (that is, by taking a weighted average). If differences in age are taken into account (by taking a weighted average using three age categories -16 to 34,35 to 54 , and 55 and older), the FMER rises to 0.743 . This relatively small (but nonetheless statistically significant) increase suggests that the age distribution of men and women workers is not very different. If, instead, differences in education are taken into account (a different weighted average using four education categories - less than a high school education, high school diploma, some college, a Bachelor's degree or more), the 
FMER rises from 0.737 to 0.782 , a large enough increase to suggest that there are important differences between men and women workers in educational attainment.

A similar increase to that for education is seen when differences across the 505 occupations are taken into account - the FMER rises from 0.737 to 0.778 - suggesting that the distribution of workers across occupations is different for men than for women.

Finally, there is an intermediate increase when race and Hispanic origin is take into account, from 0.737 to 0.751 . This stems from the fact that the percentage of the workforce that is female is different among the six race-ethnicity groups.

Some younger workers (those aged 16 to 34) tend to lack workforce and job experience, and may not have completed their education, while workers older than 54 may see some erosion of job skills, face some age-related discrimination, or take post-retirement jobs in lower-paid occupations to supplement pensions. Accordingly, since the decennial census lacks a direct measure of work experience, the remainder of the paper focuses on prime-age workers (those aged 35 to 54). Their FMER is 0.714 , lower than that for all YRFT workers.

Taking education (4 categories), occupation (505 categories), and race-ethnicity (6 categories) into account serially reduces the FMER in two cases, suggesting unevenness in earnings within education (FMER of 0.697) and race-ethnicity (FMER of 0.707) exacerbates the differences between men and women; on the other hand the FMER for workers aged 35 to 54 when accounting for occupation alone is 0.754 . When education and occupation are accounted for (a weighted average across 2,020 categories), the FMER rises to 0.777 from 0.714 . When one further accounts for race and Hispanic origin (a weighted average across 12,120 categories), there is no further increase. ${ }^{14}$

14. The latter (0.779) is not significantly different from 0.777 . 
More detail on earnings ratios for the largest occupations for each race-ethnicity group is shown in the Appendix tables.

\section{CONCLUDING COMMENT}

There is a substantial gap in median earnings between men and women that is only partially explained by age (an imperfect proxy for work experience), education, occupation, race, and Hispanic origin. However, once the other demographic characteristics are taken into account, there is no effect of race and ethnicity on the female-to-male earnings ratio. Many reasons not studied here may help to explain the difference. ${ }^{15}$

15. The General Accounting Office ("Women’s Earnings: Work Patterns Partially Explain Difference Between Men’s and Women’s Earnings,” GAO-04-35, October 2003) concluded:

Of the many factors that account for difference in earnings between men and women, our model indicated that work patterns are key. Specifically, women have fewer years of work experience, work fewer hours per year, are less likely to work a full-time schedule, and leave the labor force for longer periods of time than men. Other factors that account for earnings differences include industry, occupation, race, marital status, and job tenure. When we account for differences between male and female work patterns as well as other key factors, women earned, on average, 80 percent of what men earned in 2000...Even after accounting for key factors that affect earnings, our model could not explain all of the differences in earnings between men and women. [page 2]

See also Francine D. Blau, Marianne A. Ferber, and Anne E Winkler, The Economics of Women, Men, and Work (Fourth Edition), Prentice-Hall, 2001, for further information on the possible sources of occupational differences in earnings between men and women. 
Table 1. Ratio of Female-to-Male Median Earnings by Race and Hispanic Origin: 1999

\begin{tabular}{|c|c|c|c|c|c|c|}
\hline & & & Median Ea & rnings (\$) & & \\
\hline & Number & $\begin{array}{l}\text { Percent } \\
\text { Female }\end{array}$ & Men & Women & Ratio & $\begin{array}{c}\text { error of } \\
\text { ratio }\end{array}$ \\
\hline $\begin{array}{l}\text { All Year-round Full-Time } \\
\text { Workers }\end{array}$ & $82,977,500$ & 41.2 & 38,000 & 28,000 & 0.737 & 0.0003 \\
\hline Non-Hispanic White & $63,307,780$ & 40.2 & 40,000 & 29,000 & 0.723 & 0.0003 \\
\hline Black & $8,208,130$ & 51.6 & 30,000 & 26,000 & 0.854 & 0.0010 \\
\hline Asian & $3,196,790$ & 43.1 & 40,000 & 30,000 & 0.750 & 0.0018 \\
\hline American Indian or Alaska Native & 981,860 & 43.7 & 30,000 & 24,000 & 0.800 & 0.0028 \\
\hline $\begin{array}{l}\text { Native Hawaiian or other Pacific } \\
\text { Islander }\end{array}$ & 197,990 & 44.1 & 32,000 & 26,000 & 0.813 & 0.0075 \\
\hline Hispanic (of any race) & $7,302,530$ & 37.3 & 25,000 & 22,000 & 0.880 & 0.0014 \\
\hline & & & & & & \\
\hline $\begin{array}{l}\text { All Year-round Full-Time } \\
\text { Workers Aged 35-54 } \\
\end{array}$ & $46,316,270$ & 41.4 & 42,000 & 30,000 & 0.714 & 0.0004 \\
\hline Non-Hispanic White & $36,051,090$ & 40.1 & 45,000 & 31,000 & 0.678 & 0.0005 \\
\hline Black & $4,568,020$ & 52.1 & 33,000 & 28,000 & 0.841 & 0.0015 \\
\hline Asian & $1,750,990$ & 43.7 & 44,000 & 32,000 & 0.727 & 0.0030 \\
\hline American Indian or Alaska Native & 547,260 & 45.2 & 35,000 & 26,000 & 0.743 & 0.0038 \\
\hline $\begin{array}{l}\text { Native Hawaiian or other Pacific } \\
\text { Islander }\end{array}$ & 101,600 & 44.9 & 37,000 & 28,000 & 0.757 & 0.0077 \\
\hline Hispanic (of any race) & $3,371,474$ & 39.8 & 30,000 & 24,000 & 0.800 & 0.0018 \\
\hline
\end{tabular}

Note: The year-round full-time workers selecting two non-White races and those Hispanics selecting a non-White race are double-counted.

Source: U.S. Census Bureau, Census 2000. 
Table 2. Occupations with the Highest Median Earnings by Sex, Race, and Hispanic Origin: 1999

\begin{tabular}{|c|c|c|c|}
\hline Men & \begin{tabular}{|l|} 
Median \\
Earnings (\$)
\end{tabular} & Women & \begin{tabular}{|l} 
Median \\
Earnings (\$) \\
\end{tabular} \\
\hline \multicolumn{4}{|c|}{ All Year-Round Full-Time Workers } \\
\hline Physicians and surgeons & 140,000 & Physicians and surgeons & 88,000 \\
\hline Dentists & 110,000 & Engineering managers & 75,000 \\
\hline Chief executives & 95,000 & Dentists & 68,000 \\
\hline Lawyers & 90,000 & Lawyers & 66,000 \\
\hline $\begin{array}{l}\text { udges, magistrates, and other judicial } \\
\text { workers }\end{array}$ & 88,000 & Optometrists & 65,000 \\
\hline \multicolumn{4}{|c|}{ White alone, Not Hispanic } \\
\hline Physicians and surgeons & 150,000 & Physicians and surgeons & 90,000 \\
\hline Dentists & 110,000 & Engineering managers & 75,000 \\
\hline Chief executives & 98,000 & Dentists & 69,000 \\
\hline Lawyers & 91,000 & Lawyers & 68,000 \\
\hline $\begin{array}{l}\text { udges, magistrates, and other judicial } \\
\text { workers }\end{array}$ & 90,000 & Optometrists & 65,000 \\
\hline \multicolumn{4}{|c|}{ Black or African American alone or in combination } \\
\hline Physicians and surgeons & 110,000 & Physicians and surgeons & 79,000 \\
\hline Chief executives & 72,000 & Pharmacists & 60,000 \\
\hline Lawyers & 68,000 & Dentists & 60,000 \\
\hline $\begin{array}{l}\text { Computer and Information Systems } \\
\text { managers }\end{array}$ & 65,000 & Lawyers & 57,000 \\
\hline Computer software engineers & 60,000 & Chief executives & 55,000 \\
\hline \multicolumn{4}{|c|}{ Asian alone or in combination } \\
\hline Physicians and surgeons & 120,000 & Physicians and surgeons & 82,000 \\
\hline Chief executives & 85,000 & $\begin{array}{l}\text { Computer and Information Systems } \\
\text { managers }\end{array}$ & 66,000 \\
\hline Lawyers & 80,000 & Lawyers & 66,000 \\
\hline $\begin{array}{l}\text { Computer and Information Systems } \\
\text { managers }\end{array}$ & 75,000 & Pharmacists & 65,000 \\
\hline Pharmacists & 73,000 & Electrical and electronics engineers & 62,000 \\
\hline \multicolumn{4}{|c|}{ American I ndian or Alaska Native alone or in combination } \\
\hline Managers, all other & 48,000 & Registered nurses & 40,000 \\
\hline Registered nurses & 48,000 & Managers, all other & 35,000 \\
\hline Accountants and auditors & 42,000 & Accountants and auditors & 32,000 \\
\hline $\begin{array}{l}\text { First-line supervisors/managers of office } \\
\text { and administrative support workers }\end{array}$ & 37,000 & Elementary and middle school teachers & 32,000 \\
\hline $\begin{array}{l}\text { First-line supervisors/managers of } \\
\text { production and operating workers }\end{array}$ & 36,000 & $\begin{array}{l}\text { First-line supervisors/managers of office } \\
\text { and administrative support workers }\end{array}$ & 28,000 \\
\hline
\end{tabular}




\section{Hispanic or Latino (of any race)}

\begin{tabular}{|l|r|r|}
\hline Physicians and surgeons & 120,000 & Physicians and surgeons \\
\hline Chief executives & 75,000 Lawyers & 60,000 \\
\hline Lawyers & 74,000 Electrical and electronics engineers & 53,000 \\
\hline Computer software engineers & 60,000 Chief executives & 52,000 \\
\hline Electrical and electronics engineers & 60,000 Computer software engineers & 50,000 \\
\hline
\end{tabular}

Note: Occupations with 10,000 or more year-round full-time workers with at least 1,000 male and 1,000 female workers (there are no occupations with more than 10,000 Native Hawaiian or Other Pacific Islanders alone or in combination). Because of sampling error, the estimates in this table may not be significantly different from one another or from other occupations that are not listed in this table. Occupations with the same (rounded) median earnings are listed alphabetically.

Source: U.S. Census Bureau, Census 2000. 
Table 3. Occupations with the Lowest Median Earnings by Sex, Race, and Hispanic Origin: 1999

\begin{tabular}{|c|c|c|c|}
\hline Men & \begin{tabular}{|l} 
Median \\
Earnings (\$)
\end{tabular} & Women & \begin{tabular}{|l} 
Median \\
Earnings (\$)
\end{tabular} \\
\hline \multicolumn{4}{|c|}{ All Year-Round Full-Time Workers } \\
\hline Dishwashers & 14,000 & Dishwashers & 12,000 \\
\hline $\begin{array}{l}\text { Dining room and cafeteria attendants } \\
\text { and bartender helpers }\end{array}$ & 15,000 & Farmers and Ranchers & 12,000 \\
\hline $\begin{array}{l}\text { Counter attendants, cafeteria, food } \\
\text { concession, and coffee shop }\end{array}$ & 16,000 & $\begin{array}{l}\text { Counter attendants, cafeteria, food } \\
\text { concession, and coffee shop }\end{array}$ & 13,000 \\
\hline Food preparation workers & 16,000 & Child care workers & 14,000 \\
\hline $\begin{array}{l}\text { Combined food preparation and serving } \\
\text { workers, including fast food }\end{array}$ & 17,000 & Miscellaneous agricultural workers & 14,000 \\
\hline Cooks & 17,000 & & \\
\hline \multicolumn{4}{|c|}{ White alone, Not Hispanic } \\
\hline Dishwashers & 13,000 & Farmers and Ranchers & 12,000 \\
\hline $\begin{array}{l}\text { Dining room and cafeteria attendants } \\
\text { and bartender helpers }\end{array}$ & 16,000 & $\begin{array}{l}\text { Counter attendants, cafeteria, food } \\
\text { concession, and coffee shop }\end{array}$ & 13,000 \\
\hline $\begin{array}{l}\text { Counter attendants, cafeteria, food } \\
\text { concession, and coffee shop }\end{array}$ & 17,000 & Dishwashers & 13,000 \\
\hline $\begin{array}{l}\text { Combined food preparation and serving } \\
\text { workers, including fast food }\end{array}$ & 18,000 & Child care workers & 14,000 \\
\hline Cooks & 18,000 & Teacher assistants & 14,000 \\
\hline Food preparation workers & 18,000 & & \\
\hline \multicolumn{4}{|c|}{ Black or African American alone or in combination } \\
\hline Miscellaneous agricultural workers & 15,000 & Dishwashers & 12,000 \\
\hline $\begin{array}{l}\text { Combined food preparation and serving } \\
\text { workers, including fast food }\end{array}$ & 16,000 & Waiters and waitresses & 14,000 \\
\hline Food preparation workers & 17,000 & Bartenders & 15,000 \\
\hline Cashiers & 18,000 & $\begin{array}{l}\text { Butchers and other meat, poultry, and fish } \\
\text { processing workers }\end{array}$ & 15,000 \\
\hline \multirow[t]{9}{*}{ Cooks } & 18,000 & Cashiers & 15,000 \\
\hline & & $\begin{array}{l}\text { Combined food preparation and serving } \\
\text { workers, including fast food }\end{array}$ & 15,000 \\
\hline & & Cooks & 15,000 \\
\hline & & $\begin{array}{l}\text { Dining room and cafeteria attendants and } \\
\text { bartender helpers }\end{array}$ & 15,000 \\
\hline & & Food preparation workers & 15,000 \\
\hline & & Laundry and dry-cleaning workers & 15,000 \\
\hline & & Maids and housekeeping cleaners & 15,000 \\
\hline & & Miscellaneous agricultural workers & 15,000 \\
\hline & & $\begin{array}{l}\text { Pressers, textile, garment, and related } \\
\text { materials }\end{array}$ & 15,000 \\
\hline
\end{tabular}




\begin{tabular}{|c|c|c|}
\hline \multicolumn{3}{|c|}{ Asian alone or in combination } \\
\hline Cooks & 18,000 Sewing machine operators & 15,000 \\
\hline Food preparation workers & 18,000 Food preparation workers & 16,000 \\
\hline $\begin{array}{l}\text { Miscellaneous personal appearance } \\
\text { workers }\end{array}$ & 18,000 Miscellaneous personal appearance workers & 16,000 \\
\hline Sewing machine operators & \begin{tabular}{l|l|}
18,000 & Cashiers \\
\end{tabular} & 17,000 \\
\hline Waiters and waitresses & 19,000 Cooks & 17,000 \\
\hline & \begin{tabular}{l|l} 
Waiters and waitresses \\
\end{tabular} & 17,000 \\
\hline \multicolumn{3}{|c|}{ American I ndian or Alaska Native alone or in combination } \\
\hline Cooks & \begin{tabular}{l|l|l|}
16,000 & Cooks \\
\end{tabular} & 14,000 \\
\hline Cashiers & 17,000 Cashiers & 15,000 \\
\hline Janitors and building cleaners & 20,000 anitors and building cleaners & 15,000 \\
\hline $\begin{array}{l}\text { Nursing, psychiatric, and home health } \\
\text { aides }\end{array}$ & 20,000 Nursing, psychiatric, and home health aides & 18,000 \\
\hline $\begin{array}{l}\text { Bookkeeping, accounting, and auditing } \\
\text { clerks }\end{array}$ & 24,000 Retail salespersons & 18,000 \\
\hline $\begin{array}{l}\text { Laborers and freight, stock, and } \\
\text { material movers, hand } \\
\end{array}$ & 24,000 & \\
\hline \multicolumn{3}{|c|}{ Hispanic or Latino (of any race) } \\
\hline Dishwashers & 13,000 Dishwashers & 12,000 \\
\hline $\begin{array}{l}\text { Combined food preparation and serving } \\
\text { workers, including fast food }\end{array}$ & 15,000 Child care workers & 13,000 \\
\hline $\begin{array}{l}\text { Dining room and cafeteria attendants } \\
\text { and bartender helpers }\end{array}$ & 15,000 Cooks & 13,000 \\
\hline Food preparation workers & \begin{tabular}{l|l|}
15,000 & Dining room and cafeteria attendants and \\
bartender helpers
\end{tabular} & 13,000 \\
\hline Miscellaneous agricultural workers & 15,000 Miscellaneous agricultural workers & 13,000 \\
\hline Sewing machine operators & 15,000 & \\
\hline
\end{tabular}

Note: Occupations with 10,000 or more year-round full-time workers with at least 1,000 male and 1,000 female workers (there are no occupations with more than 10,000 Native Hawaiian or Other Pacific Islanders alone or in combination). Because of sampling error, the estimates in this table may not be significantly different from one another or from other occupations that are not listed in this table. Occupations with the same (rounded) median earnings are listed alphabetically.

Source: U.S. Census Bureau, Census 2000. 
Table 4. Ratio of Female-to-Male Median Earnings, Controlling for Age, Education, Occupation, Race, and Hispanic Origin: 1999

\begin{tabular}{|l|r|l|r|}
\hline & Ratio & Ratio \\
\hline All Year-round Full-time workers & 0.737 & \begin{tabular}{l} 
All Year-round Full-time workers \\
\hline Controlling for ...
\end{tabular} & Controlling for ... \\
\hline Age & 0.743 & & 0.714 \\
\hline Race and Hispanic origin & 0.751 & Race and Hispanic origin & 0.707 \\
\hline Education (ages 25 and older) & 0.782 & Education & 0.697 \\
\hline Occupation & 0.778 & Occupation & 0.754 \\
\hline & & Education and Occupation & 0.777 \\
\hline & & $\begin{array}{l}\text { Education, Occupation, Race and } \\
\text { Hispanic origin }\end{array}$ & 0.779 \\
\hline
\end{tabular}

Note: Controls for race and Hispanic origin double-count individuals selecting two non-White races and those Hispanics selecting a non-White race.

Source: U.S. Census Bureau, Census 2000. 
Figure 1.

Ratio of Earnings of Race Groups and Hispanics to Earnings for

Non-Hispanic Whites by Earnings Percentile: 1999

(All civilian noninstitutionalized year-round, full-time workers. Data based on a sample.

For information on confidentiality protection, sampling error, nonsampling error, and definitions, see www.census.gov/prod/cen2000/doc/sf3.pdf)

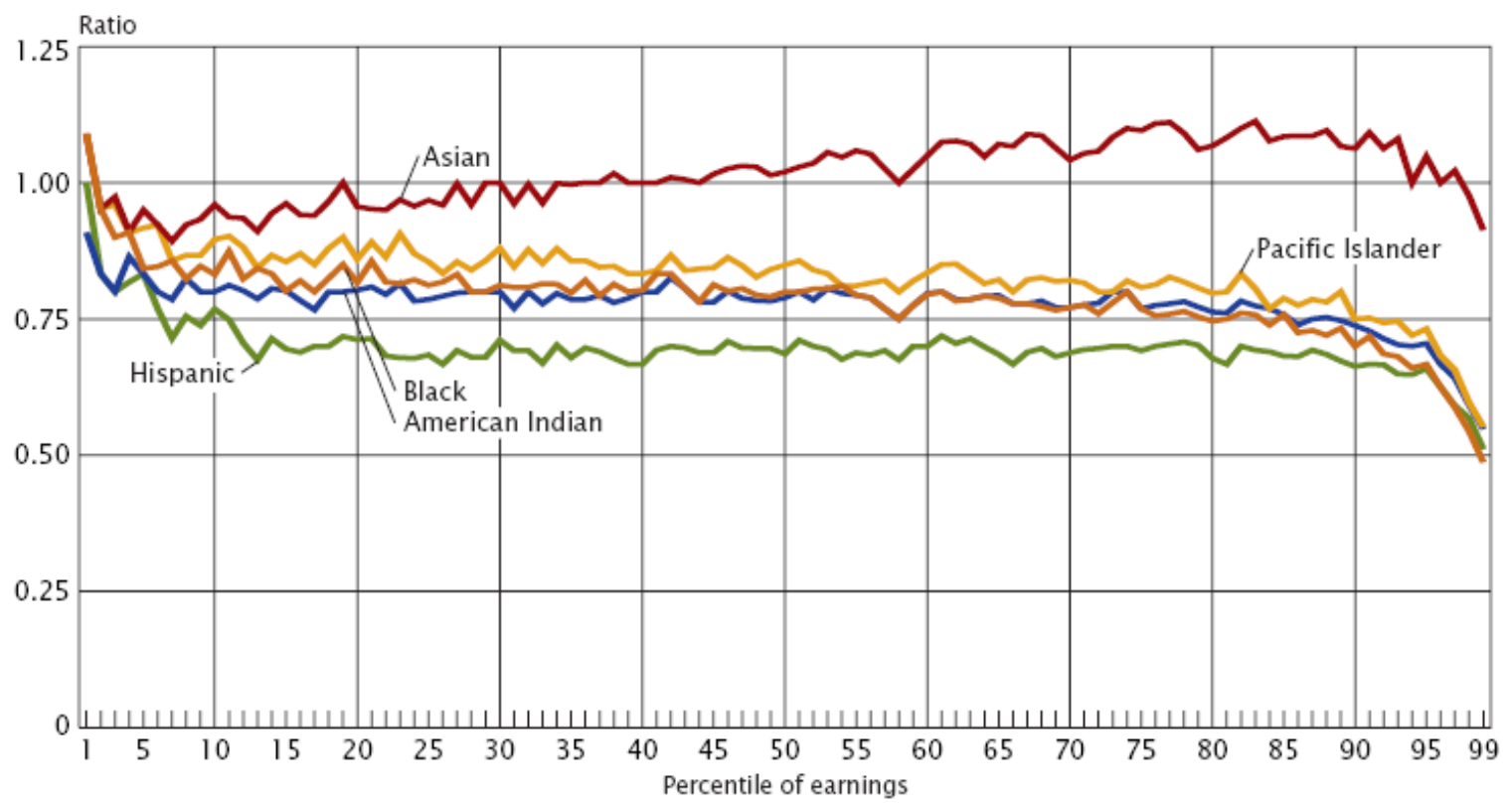

Note: White $=$ White alone; Black = Black or African American alone or in combination; Asian = Asian alone or in combination;

Pacific Islander $=$ Native Hawaiian or other Pacific Islander alone or in combination; American Indian = American Indian or

Alaska Native alone or in combination; Hispanic = Hispanic or Latino (of any race).

Source: U.S. Census Bureau, Census 2000. 
Appendix Table A1. Female-to-Male Median Earnings Ratio for Large Occupations for Non-Hispanic White Workers Aged 35-54, by Education: 1999

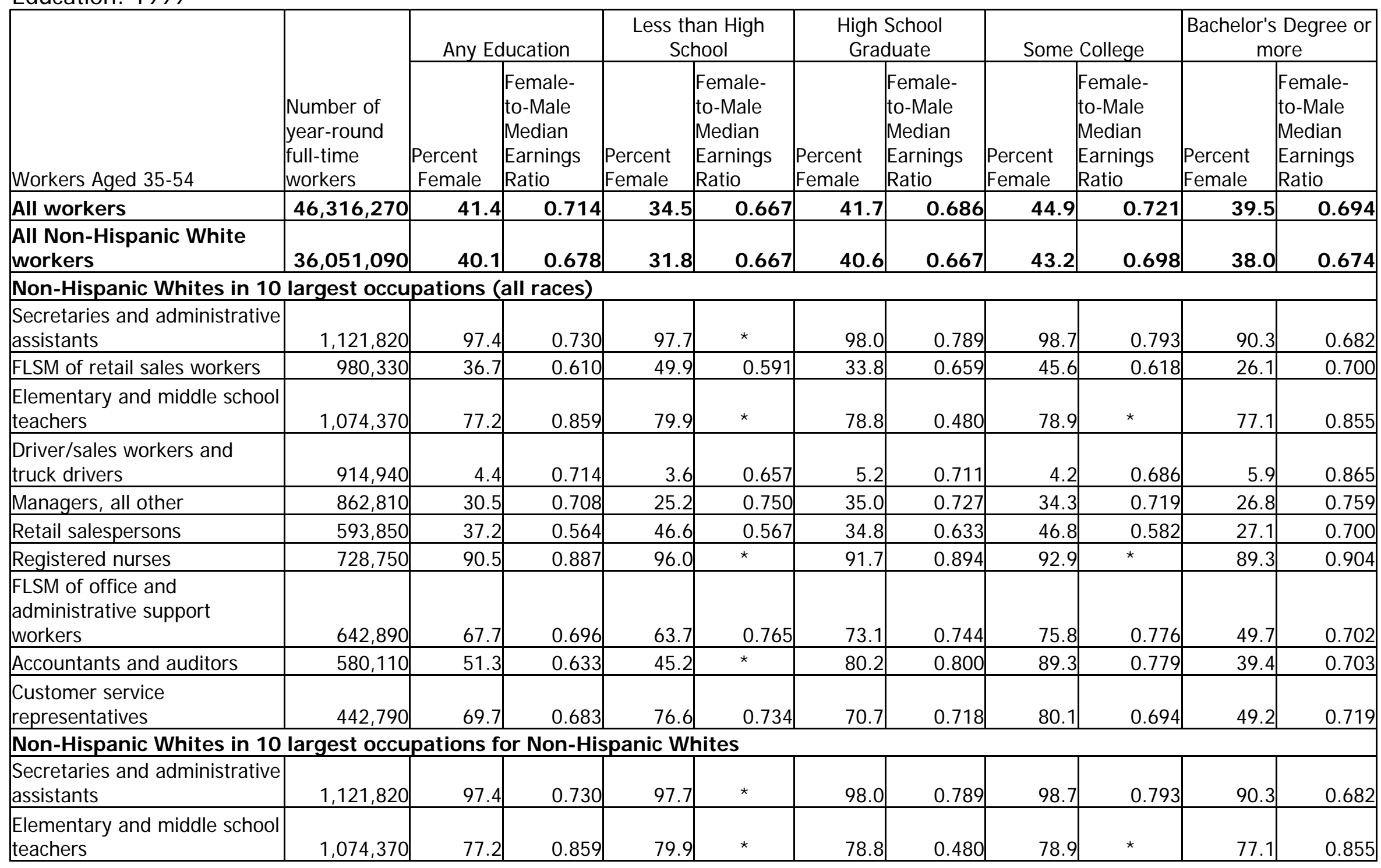




\begin{tabular}{|c|c|c|c|c|c|c|c|c|c|c|c|}
\hline FLSM of retail sales workers & 980,330 & 36.7 & 0.610 & 49.9 & 0.591 & 33.8 & 0.659 & 45.6 & 0.618 & 26.1 & 0.700 \\
\hline $\begin{array}{l}\text { Driver/sales workers and } \\
\text { truck drivers }\end{array}$ & 914,940 & 4.4 & 0.714 & 3.6 & 0.657 & 5.2 & 0.711 & 4.2 & 0.686 & 5.9 & 0.865 \\
\hline Managers, all other & 862,810 & 30.5 & 0.708 & 25.2 & 0.750 & 35.0 & 0.727 & 34.3 & 0.719 & 26.8 & 0.759 \\
\hline Registered nurses & 728,750 & 90.5 & 0.887 & 96.0 & $*$ & 91.7 & 0.894 & 92.9 & * & 89.3 & 0.904 \\
\hline $\begin{array}{l}\text { FLSM of office and } \\
\text { administrative support } \\
\text { workers }\end{array}$ & 642,890 & 67.7 & 0.696 & 63.7 & 0.765 & 73.1 & 0.744 & 75.8 & 0.776 & 49.7 & 0.702 \\
\hline Retail salespersons & 593,850 & 37.2 & 0.564 & 46.6 & 0.567 & 34.8 & 0.633 & 46.8 & 0.582 & 27.1 & 0.700 \\
\hline Accountants and auditors & 580,110 & 51.3 & 0.633 & 45.2 & $*$ & 80.2 & 0.800 & 89.3 & 0.779 & 39.4 & 0.703 \\
\hline Chief executives & 575,290 & 17.5 & 0.663 & 16.5 & 0.667 & 22.0 & 0.650 & 21.4 & 0.662 & 15.1 & 0.732 \\
\hline
\end{tabular}

NOTES: * = fewer than 1,000 male or female workers. FLSM=First-line supervisors/managers. Occupations listed in order of size.

Source: U.S. Census Bureau, Census 2000. 
Appendix Table A2. Female-to-Male Median Earnings Ratio for Large Occupations for Black Workers Aged 35-54, by Education: 1999

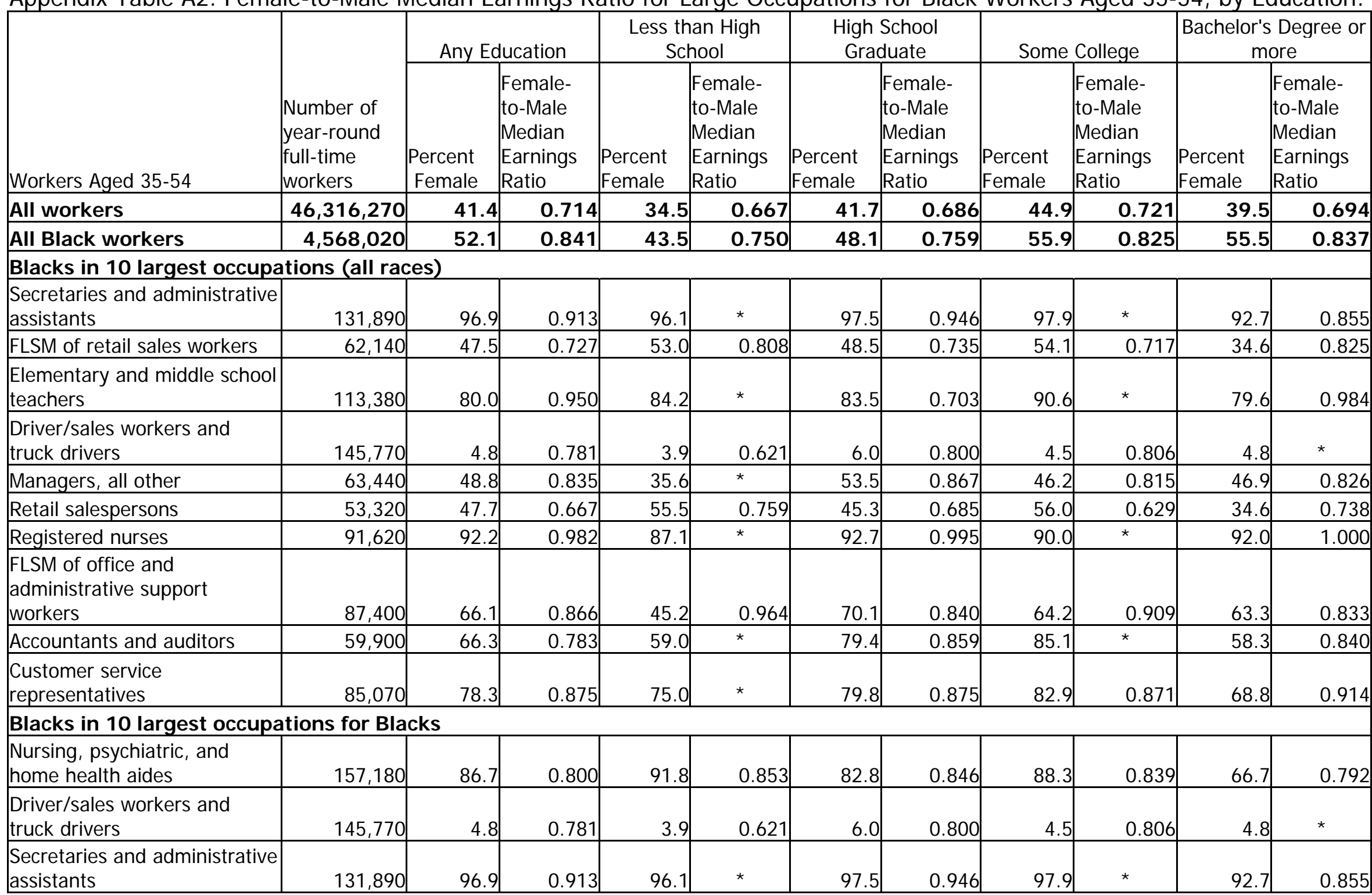




\begin{tabular}{|c|c|c|c|c|c|c|c|c|c|c|c|}
\hline $\begin{array}{l}\text { Elementary and middle school } \\
\text { teachers }\end{array}$ & 113,380 & 80.0 & 0.950 & 84.2 & * & 83.5 & 0.703 & 90.6 & * & 79.6 & 0.984 \\
\hline Registered nurses & 91,620 & 92.2 & 0.982 & 87.1 & $*$ & 92.7 & 0.995 & 90.0 & $*$ & 92.0 & 1.000 \\
\hline $\begin{array}{l}\text { Customer service } \\
\text { representatives }\end{array}$ & 85,070 & 78.3 & 0.875 & 75.0 & $*$ & 79.8 & 0.875 & 82.9 & 0.871 & 68.8 & 0.914 \\
\hline $\begin{array}{l}\text { Laborers and freight, stock, } \\
\text { and material movers, hand }\end{array}$ & 75,150 & 19.4 & 0.852 & 15.7 & 0.827 & 21.7 & 0.936 & 19.7 & 0.836 & 19.3 & $*$ \\
\hline
\end{tabular}

NOTES: * = fewer than 1,000 male or female workers. FLSM=First-line supervisors/managers. Occupations listed in order of size.

Source: U.S. Census Bureau, Census 2000. 
Appendix Table A3. Female-to-Male Median Earnings Ratio for Large Occupations for Asian Workers Aged 35-54, by Education: 1999

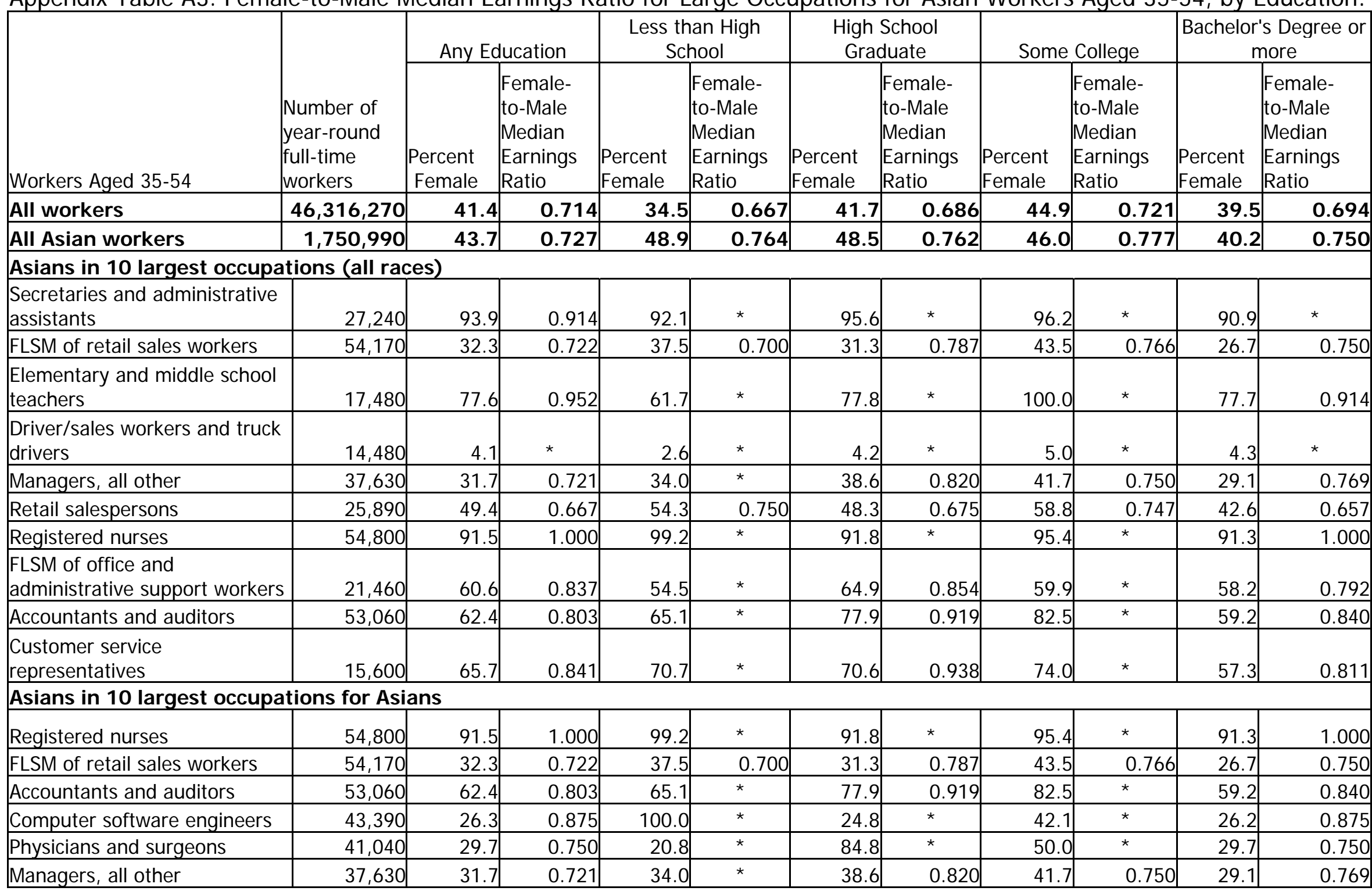




\begin{tabular}{|c|c|c|c|c|c|c|c|c|c|c|c|}
\hline Cooks & 29,080 & 32.4 & 0.944 & 30.6 & 1.000 & 35.1 & 0.801 & 33.8 & 0.952 & 34.7 & * \\
\hline Cashiers & 28,740 & 62.4 & 0.818 & 62.6 & 0.835 & 63.8 & 0.795 & 66.7 & 0.833 & 56.8 & 0.740 \\
\hline Computer programmers & 27,350 & 35.5 & 0.908 & 22.8 & * & 34.2 & * & 31.6 & * & 35.8 & 0.896 \\
\hline $\begin{array}{l}\text { Secretaries and administrative } \\
\text { assistants }\end{array}$ & 27,240 & 93.9 & 0.914 & 92.1 & * & 95.6 & * & 96.2 & * & 90.9 & * \\
\hline
\end{tabular}

NOTES: $*=$ fewer than 1,000 male or female workers. FLSM=First-line supervisors/managers. Occupations listed in order of size.

Source: U.S. Census Bureau, Census 2000. 
Appendix Table A4. Female-to-Male Median Earnings Ratio for Large Occupations for American Indian and Alaska Native Workers Aged 35-54, by Education: 1999

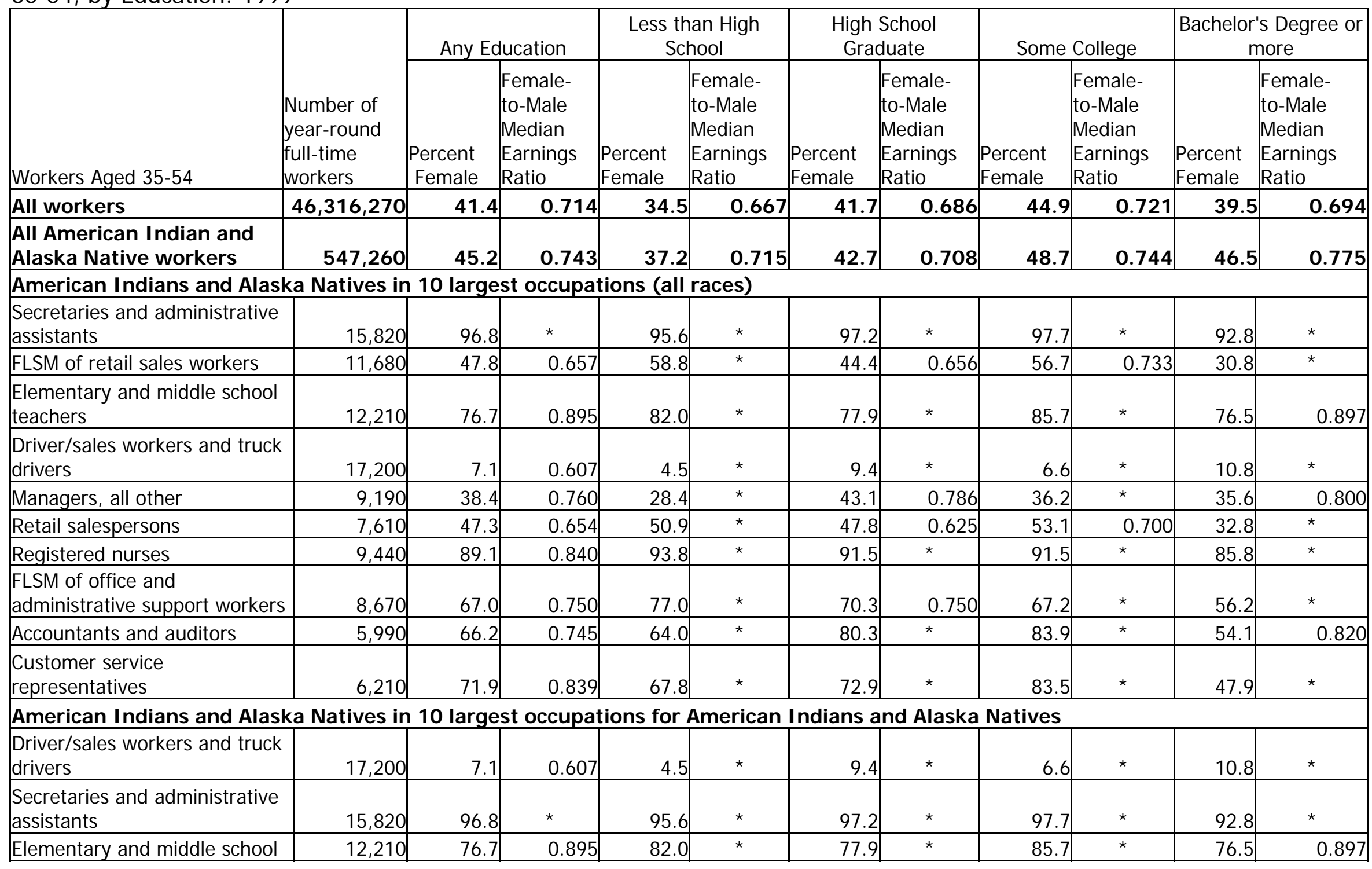




\begin{tabular}{|c|c|c|c|c|c|c|c|c|c|c|c|}
\hline teachers & & & & & & & & & & & \\
\hline FLSM of retail sales workers & 11,680 & 47.8 & 0.657 & 58.8 & * & 44.4 & 0.656 & 56.7 & 0.733 & 30.8 & * \\
\hline J anitors and building cleaners & 9,520 & 25.6 & 0.696 & 35.4 & $*$ & 19.6 & $*$ & 24.7 & $*$ & 13.6 & $*$ \\
\hline Registered nurses & 9,440 & 89.1 & 0.840 & 93.8 & $*$ & 91.5 & $*$ & 91.5 & * & 85.8 & $*$ \\
\hline Managers, all other & 9,190 & 38.4 & 0.760 & 28.4 & $*$ & 43.1 & 0.786 & 36.2 & * & 35.6 & 0.800 \\
\hline $\begin{array}{l}\text { Nursing, psychiatric, and home } \\
\text { health aides }\end{array}$ & 8,750 & 87.1 & 0.793 & 92.4 & $*$ & 83.7 & $*$ & 90.2 & $*$ & 74.3 & $*$ \\
\hline $\begin{array}{l}\text { FLSM of office and } \\
\text { administrative support workers }\end{array}$ & 8,670 & 67.0 & 0.750 & 77.0 & $*$ & 70.3 & 0.750 & 67.2 & * & 56.2 & $*$ \\
\hline Retail salespersons & 7,610 & 47.3 & 0.654 & 50.9 & * & 47.8 & 0.625 & 53.1 & 0.700 & 32.8 & $*$ \\
\hline
\end{tabular}

NOTES: * = fewer than 1,000 male or female workers. FLSM=First-line supervisors/managers. Occupations listed in order of size.

Source: U.S. Census Bureau, Census 2000. 
Appendix Table A5. Female-to-Male Median Earnings Ratio for Large Occupations for Native Hawaiian and Other Pacific I slander Workers Aged 35-54, by Education: 1999

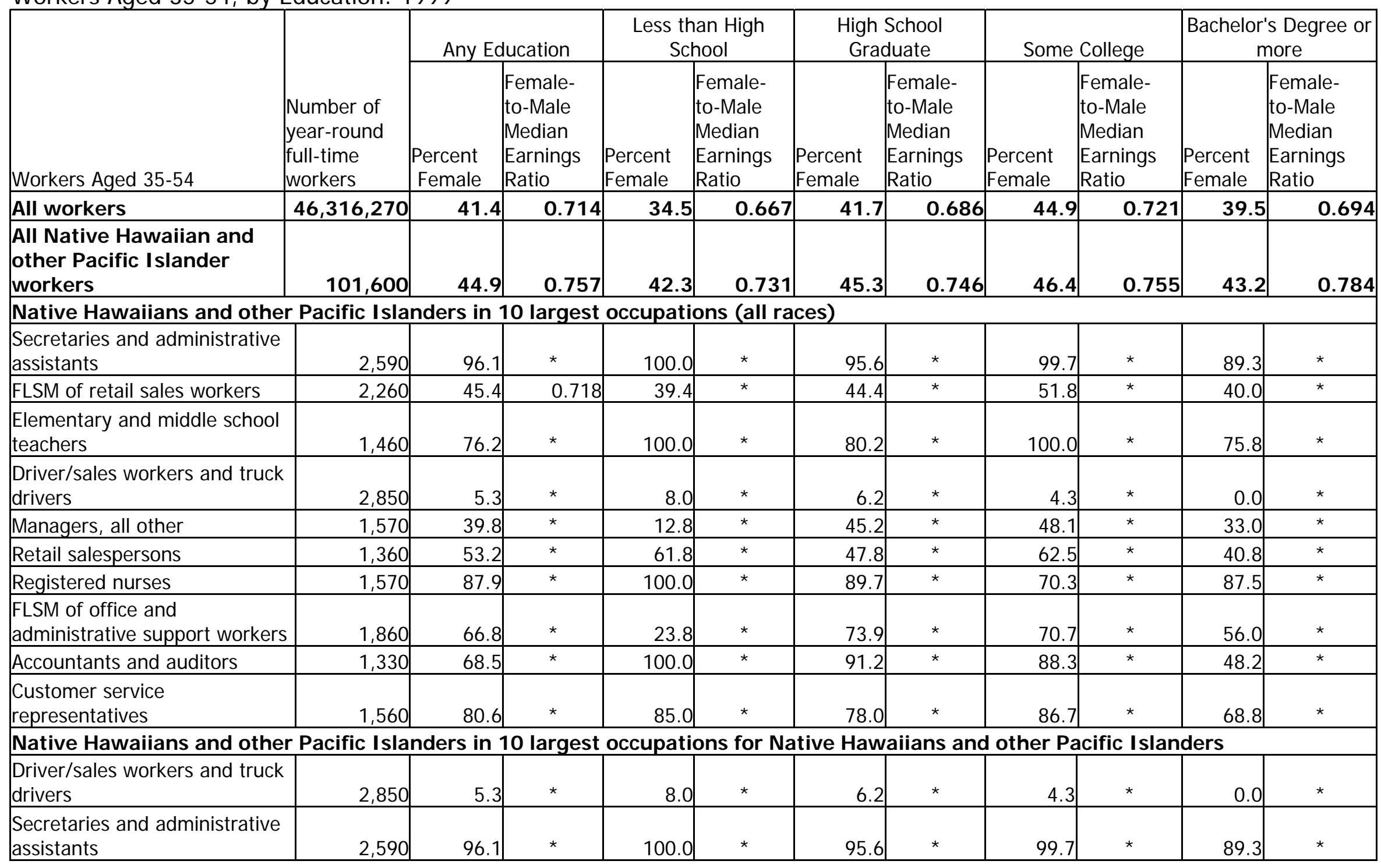




\begin{tabular}{|c|c|c|c|c|c|c|c|c|c|c|c|}
\hline FLSM of retail sales workers & 2,260 & 45.4 & 0.718 & 39.4 & * & 44.4 & $*$ & 51.8 & $*$ & 40.0 & * \\
\hline J anitors and building cleaners & 1,950 & 31.6 & $*$ & 30.3 & $*$ & 31.1 & $*$ & 33.9 & * & 14.7 & * \\
\hline \begin{tabular}{|l} 
FLSM of office and \\
administrative support workers
\end{tabular} & 1,860 & 66.8 & * & 23.8 & * & 73.9 & * & 70.7 & * & 56.0 & * \\
\hline Managers, all other & 1,570 & 39.8 & $*$ & 12.8 & $*$ & 45.2 & $*$ & 48.1 & $*$ & 33.0 & $*$ \\
\hline $\begin{array}{l}\text { Customer service } \\
\text { representatives }\end{array}$ & 1,560 & 80.6 & $*$ & 85.0 & $*$ & 78.0 & $*$ & 86.7 & * & 68.8 & * \\
\hline Cashiers & 1,450 & 82.7 & * & 87.8 & * & 80.0 & * & 84.0 & $*$ & 72.5 & * \\
\hline
\end{tabular}

NOTES: * = fewer than 1,000 male or female workers (no occupation-education combination has more than 500 male and 500 female Native Hawaiian and other Pacific Islander workers). Occupations listed in order of size.

FLSM=First-line supervisors/managers.

Source: U.S. Census Bureau, Census 2000. 
Appendix Table A6. Female-to-Male Median Earnings Ratio for Large Occupations for Hispanic Workers Aged 35-54, by Education: 1999

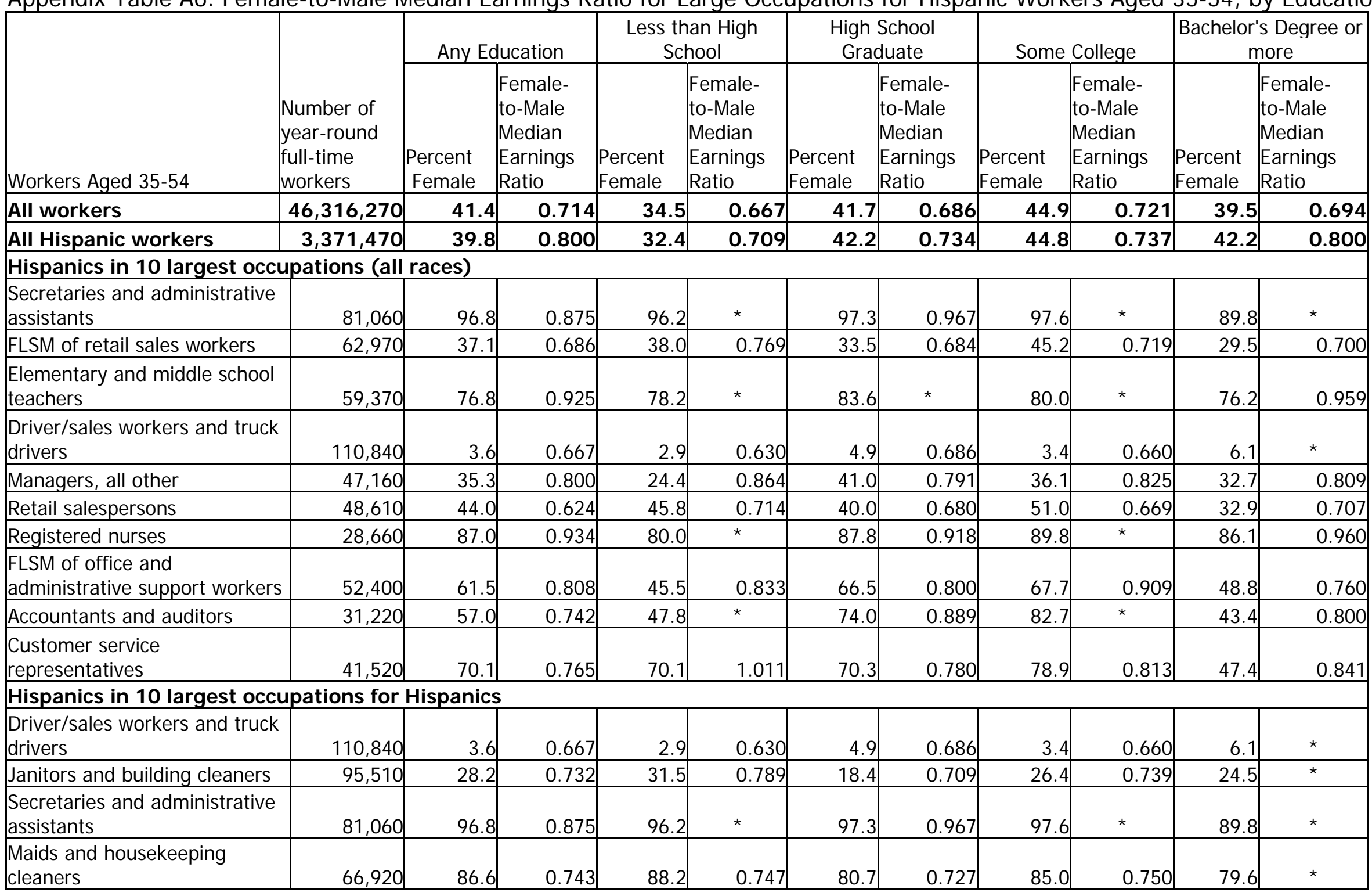




\begin{tabular}{|c|c|c|c|c|c|c|c|c|c|c|c|}
\hline FLSM of retail sales workers & 62,970 & 37.1 & 0.686 & 38.0 & 0.769 & 33.5 & 0.684 & 45.2 & 0.719 & 29.5 & 0.700 \\
\hline Production workers, all other & 62,810 & 35.0 & 0.680 & 36.4 & 0.727 & 26.4 & 0.656 & 36.6 & 0.662 & 30.5 & $*$ \\
\hline $\begin{array}{l}\text { Elementary and middle school } \\
\text { teachers }\end{array}$ & 59,370 & 76.8 & 0.925 & 78.2 & * & 83.6 & * & 80.0 & * & 76.2 & 0.959 \\
\hline $\begin{array}{l}\text { FLSM of production and } \\
\text { operating workers }\end{array}$ & 57,840 & 23.6 & 0.676 & 25.7 & 0.620 & 21.0 & 0.721 & 24.3 & 0.732 & 19.1 & * \\
\hline Cooks & 55,340 & 37.3 & 0.778 & 37.5 & 0.722 & 33.5 & 0.744 & 40.0 & 0.801 & 25.2 & $*$ \\
\hline \begin{tabular}{|l|} 
FLSM of office and \\
administrative support workers
\end{tabular} & 52,400 & 61.5 & 0.808 & 45.5 & 0.833 & 66.5 & 0.800 & 67.7 & 0.909 & 48.8 & 0.760 \\
\hline
\end{tabular}

NOTES: * = fewer than 1,000 male or female workers. FLSM=First-line supervisors/managers. Occupations listed in order of size.

Source: U.S. Census Bureau, Census 2000. 


\section{APPENDIX B: ACCURACY OF THE ESTIMATES}

The data contained in this paper are based on the sample of households who responded to the Census 2000 long form. Nationally, approximately one out of every six housing units (15.9 percent of the final housing unit count) was included in this sample. As a result, the sample estimates may differ somewhat from the100-percent figures that would have been obtained if all housing units, people within those housing units, and people living in group quarters had been enumerated using the same questionnaires, instructions, enumerators, and so forth. The sample estimates also differ from the values that would have been obtained from different samples of housing units, and hence of people living in those housing units, and people living in group quarters. The deviation of a sample estimate from the average of all possible samples is called the sampling error.

In addition to the variability that arises from the sampling procedures, both sample data and 100-percent data are subject to nonsampling error. Nonsampling error may be introduced during any of the various complex operations used to collect and process data. Such errors may include: not enumerating every household or every person in the population, failing to obtain all required information from the respondents, obtaining incorrect or inconsistent information, and recording information incorrectly. In addition, errors can occur during the field review of the enumerators' work, during clerical handling of the census questionnaires, or during the electronic processing of the questionnaires.

While it is impossible to completely eliminate error from an operation as large and complex as the decennial census, the Census Bureau attempts to control the sources of such error during the data collection and processing operations. The primary sources of error and the 
programs instituted to control error in Census 2000 are described in detail in Summary File 3

Technical Documentation under Chapter 8, “Accuracy of the Data,” located at

$<$ www.census.gov/prod/cen2000/doc/sf3.pdf > .

Nonsampling error may affect the data in two ways: (1) errors that are introduced randomly will increase the variability of the data and, therefore, should be reflected in the standard errors; and (2) errors that tend to be consistent in one direction will bias both sample and 100-percent data in that direction. For example, if respondents consistently tend to underreport their earnings, then the resulting proportions of earners by income category will tend to be understated for the higher income categories and overstated for the lower income categories. Such biases are not reflected in the standard errors.

The obvious source of potential error is misreporting by the respondent - either misreporting of their occupation, their earnings, or one of their classifying variables. According to the Census 2000 Content Reinterview Study, questions about wages and salaries and selfemployment income showed only "moderate" inconsistency. ${ }^{16}$

Another potential source of measurement error is not a mistake on the part of the respondent, but rather the presence of complicating factors. Not everyone has just one job and one occupation. Others might have part-time jobs to help bring in extra money - such as a schoolteacher working part-time as a retail salesperson during the holiday season. Yet others might report certain occupations for historical reasons - for example, a full-time factory wage

16. Phyllis Singer and Sharon R. Ennis, "Census 2000 Content Reinterview Survey: Accuracy of Data for Selected Population and Housing Characteristics as Measured by Reinterview," Census 2000 Evaluation B.5, September 24, 2003, at <http://www.census.gov/pred/www/eal_toprpts.htm\#CONTENT>. The authors note that "[Content Reinterview Survey] respondents were asked if the sample person received any wages, salary, commissions, bonuses, or tips in 1999...Households with female sample persons showed less inconsistency (low) than households with male sample persons (moderate).” [page 45] 
earner might also be self-employed part-time as a farmer, and report farming as his occupation since his father and grandfather were farmers. Since the decennial census long form asked for the total of all earnings but only for the primary occupation, if multiple job holding was common, the earnings of schoolteachers and farmers, in the examples above, would be over-estimated. ${ }^{17}$

${ }^{17}$ According to the Bureau of Labor Statistics web site, based on the Current Population Survey, in April 2000, 5.7 percent of the employed (16 years and older) held multiple jobs. 